\title{
Анатолій ЛУЦИк
}

кандидат економічних наук, доцент, Західноукраїнський національний університет, Тернопіль, Україна, a.lutsyk@wunu.edu.ua

ORCID ID: 0000-0001-5131-7444

\section{ОБГРУНТУВАННЯ ПРІОРИТЕТНОСТI ДОСЯГНЕННЯ ЦІАЕЙ СТАИОГО РОЗВИТКУ У ЗДІЙСНЕННІ ФІСКААЬНОÏ ПОАІТИКИ}

Вступ. З утвердженням глобального процесу сталого розвитку зростає потреба наукових досліджень його забезпечення. У цьому контексті важливим є системне використання інструментів фріскальної політики у досягненні цілей сталого розвитку, що спричинятиме позитивний ефект не лише в глобальному маситабі, а й покращуватиме соціально-економічне становище в Україні.

Мета - дослідити взаємозв'язок фріскальної політики та сталого розвитку, аргументувати пріоритетність використання інструментарію фріскальної політики у досягненні цілей сталого розвитку, а також оцінити дієвість їх використання у досягненні цих цілей.

Mетоди. У дослідженні фріскальної політики при досягненні цілей сталого розвитку застосовано загальнонаукові та спеціальні методи, а саме: порівняння, групування, графрічного та табличного аналізу.

Результати. Обгрунтовано, що фріскальна політика має значний потенціал у забезпеченні сталого розвитку. Будучи різновидом державної політики, вона здійснює вплив на соціально-економічні процеси, які відбуваються у країні. Аргументовано, що в українській практиці використання інструментарію фріскальної політики не забезпечує прогрес у досягненні цілей сталого розвитку. Використання податкового та видаткового регулювання, а також інструменту боргових фрінансів відбувається за відсутності стратегії їх взаємоузгодження та підпорядкування однаковим цільовим параметрам. Це призводить до зростання соціальних розривів і диспропорцій, погіршує економічний стан та навколишнє природне середовища. Доведено, що досягнення цілей сталого розвитку сприятиме покращенню соціально-економічного становища в Україні та стану державних фрінансів.

Перспективи. Подальші наукові дослідження доцільно спрямувати на пошук шляхів щодо досягнення визначених глобальних цілей сталого розвитку з допомогою раціоналізації державних рішень щодо синергетичного використання інструментів фріскальної політики.

Ключові слова: сталий розвиток, фріскальна політика, цілі сталого розвитку, інструменти фріскальної політики.

Табл.: 1, рис.: 3, бібл.: 17.

( Анатолій Ігорович Луцик, 2021 


\section{Анатолий лУЦЫк}

кандидат экономических наук, доцент, Западноукраинский национальный университет, Тернополь, Украина

\section{ОБОСНОВАНИЕ ПРИОРИТЕТНОСТИ ДОСТИЖЕНИЯ ЦЕАЕЙ УСТОЙЧИВО- ГО РАЗВИТИЯ ПРИ ОСУЩЕСТВАЕНИИ ФИСКАМЬНОЙ ПОАИТИКИ}

Введение. С утверждением глобального процесса устойчивого развития возрастает потребность научных исследований его обеспечения. В этом контексте важно системное использование инструментов фрискальной политики для достижения целей устойчивого развития, что вызовет положительный эфффект не только в глобальном масштабе, но и улучшит социально-экономическое положение в Украине.

Цель - исследовать взаимосвязь фискальной политики и устойчивого развития, аргументировать приоритетность использования инструментария фрискальной политики в достижении целей устойчивого развития, а также оценить эффрективность их использования в достижении этих целей.

Методы. В исследовании фрискальной политики при достижении целей устойчивого развития применены общенаучные и специальные методы, а именно: сравнение, группировка, графического и табличного анализа.

Результаты. Обосновано, что фрискальная политика имеет значительный потенциал в обеспечении устойчивого развития. Являясь разновидностью государственной политики, она оказывает влияние на социально-экономические процессы, происходящие в стране. Аргументировано, что в украинской практике использования инструментария фрискальной политики не обеспечивает прогресс в достижении целей устойчивого развития. Использование налогового регулирования с помощью государственных расходов, а также инструмента долговых фринансов происходит при отсутствии стратегии их взаимосвязи и подчинения одинаковым целевым параметрам. Это приводит к росту социальных разрывов и диспропорций, ухудшает экономическое состояние и состояние окружающей среды. Доказано, что достижение целей устойчивого развития будет способствовать улучшению социальноэкономического положения в Украине и состояния государственных финансов.

Перспективы. Дальнейшие научные исследования целесообразно направить на поиск путей по достижению определенных глобальных целей устойчивого развития за счет рационализации государственных решений относительно синергетического использования инструментов фрискальной политики.

Ключевые слова: устойчивое развитие, фрискальная политика, цели устойчивого развития, инструменты фрискальной политики.

\section{Anatolii LUTSYK}

Ph. D. (Economics), Assoc. Prof., West Ukrainian National University, Ternopil, Ukraine,

a.lutsyk@wunu.edu.ua

ORCID ID: 0000-0001-5131-7444

SUBSTANTIATION OF PRIORITY OF ACHIEVING THE GOALS OF SUSTAINABLE DEVELOPMENT IN THE IMPLEMENTATION OF FISCAL POLICY

Introduction. With the approval of the global process of sustainable development increases the need for its research support. In this context, it is important to systematically use the instru- 
ments of fiscal policy in achieving the goals of sustainable development, which will have a positive effect not only on a global scale, but also improve the socio-economic situation in Ukraine.

The purpose of the article is to investigate the relationship between fiscal policy and sustainable development, to argue the priority of using the tools of fiscal policy in achieving the goals of sustainable development, as well as to assess the effectiveness of their use in achieving these goals.

Methods. In the exploration of fiscal policy to achieve the goals of sustainable development used general and special methods, namely: comparison, grouping, graphical and tabular analysis.

Results. It is substantiated that fiscal policy has a significant potential in ensuring sustainable development, being a kind of public policy, it has an impact on socio-economic processes taking place in the country. It is argued that in Ukrainian practice the use of fiscal policy tools does not provide progress in achieving sustainable development goals. The use of tax and expenditure regulation, as well as the instrument of debt finance occurs in the absence of a strategy for their coordination and subordination to the same target parameters. This leads to growing social gaps and imbalances, worsens the economic situation and the environment. It is proved that achieving the goals of sustainable development will help to improve the socioeconomic situation in Ukraine and the state of public finances.

Perspectives. Further research should be aimed at finding ways to achieve defined global goals of sustainable development by rationalizing of government decisions on the synergistic use of fiscal policy instruments.

Keywords: sustainable development, fiscal policy, sustainable development goals, fiscal policy instruments.

JEL Classification: E62, H30, Q23.

Постановка проблеми. Фіскальна політика держав світу є системним способом досягнення визначених цілей і завдань суспільства. Кожна країна визначає для себе цілі та завдання фіскальної політики залежно від стадії розвитку, соціально-економічного становища, природних, географічних та інших умов. Концепція сталого розвитку, її глобальні цілі $€$ спільними та важливими для усіх країн світу, адже були визнані як орієнтир розвитку та реалізовуються Організацією Об'єднаних Націй.

На сьогодні вже беззаперечним $€$ фракт негативного та незворотного впливу людської діяльності на екологію та довкілля планети. Характерними є проблеми бідності та голоду у різних частинах світу. Незважаючи на економічний і інтелектуальний розвиток людства, все більш загрозливим стає порушення миру, військові конфлікти. Це лише незначна кількість проблемних цілей сталого розвитку, які $€$ характерними і для України.

Фіскальна політика $є$ тією державною політикою, з допомогою якої можна вирішувати зазначені проблеми. Поряд з цим, вона також виступає політикою, яка провокує виникнення таких проблем чи їх загострює. Тому дослідження ефективного використання фіскальної політики у досягненні цілей сталого розвитку та мінімізації негативного впливу людства на суспільний розвиток набувають особливої актуальності.

Аналіз останніх досліджень і публікацій. Проблематика сталого розвитку в останні роки набуває особливої актуаль- 
ності. Різні аспекти забезпечення сталого розвитку розглядають як зарубіжні, так і українські науковці. Так, використання окремих інструментів, елементів та механізмів державних фрінансів у досягненні цілей сталого розвитку досліджено у працях Ж. Аткінсона [1], В. Андрущенка [2], О. Длугопольського, В. Козюка [3], О. Тулай [4], Е. Лібанової [5] та ін.

Незважаючи на значне поширення досліджень з проблематики сталого розвитку, глибшого аналізу потребує проблематика результативності використання інструментів та складових фіскальної політики у досягненні цілей сталого розвитку.

Метою дослідження є обґрунтування ролі та перспектив використання фріскальної політики України у забезпеченні сталого суспільного розвитку, зокрема відповідності механізму використання інструментарію фіскальної політики визначеним цілям сталого розвитку, а також прогресу у досягненні цих цілей за допомогою синергетичного використання інструментарію фріскальної політики.

Виклад основного матеріалу дослідження. Глобальні цілі сталого розвитку кінцевою метою мають створення та збереження можливостей для існування людства. Фіскальна політика в сучасних умовах дає змогу оперувати державними фрінансами задля досягнення визначених цілей. Актуальним у досягненні цілей фіскальної політики є їх узгодження з цілями сталого розвитку.

За своєю суттю фіскальна політика передбачає використання фіскальних інструментів (податкового регулювання, видаткового та трансфертного регулювання, боргових інструментів) з метою вирішення конкретних стратегічних і тактичних завдань. Як правило, такі завдання фіскальної політики пов'язані з соціально-економічним розвитком країни. Тобто кінцевою ціллю фріскальної політики має бути покращення якості життя населення країни, а не зростання обсягів виробництва чи покращення стану платіжного і торгового балансу. Але науково-технічний прогрес та прагнення до соціально-економічного росту створили дисбаланси в соціально-економічному розвитку різних країн, а також призвели до виснаження природних ресурсів планети і, як наслідок, до появи природних катаклізмів та аномалій.

Ідею визначення цілей сталого розвитку було запропоновано на конференції ООН у Ріо-де-Жанейро у 2012 р., що прийшли на зміну цілям розвитку тисячоліття[6]. А у вересні 2015 р. на Саміті ООН в Нью-Йорку було затверджено 17 цілей сталого розвитку на період з 2016 до 2030 р. Україна разом $з$ іншими країнами - членами ООН приєдналася до глобального процесу забезпечення сталого розвитку та досягнення цих цілей. Деякі з них можна згрупувати за спільними ознаками. На рис. 1 відображено можливі способи використання інструментів фіскальної політики у досягненні глобальних цілей сталого розвитку, що характеризуються соціальною проблематикою.

Вказані цілі є глобальними, оскільки проблема бідності, голоду, соціальної нерівності $€$ характерними для багатьох країн світу. Особливо важливим $€$ забезпечення миру та справедливості. На жаль, незважаючи на проголошення курсу ринкових і демократичних перетворень за роки незалежності ці проблеми не лише залишились, а й загострились в Україні. Фіскальні інструменти, які використовують в світовій практиці, завжди підпорядковуються вирішенню суспільних проблем. Відзначені цілі $€$ актуальними для нашої країни проблемами, зумовлюють одна одну та вимагають їх вирішення навіть без врахування приєднання Украї- 


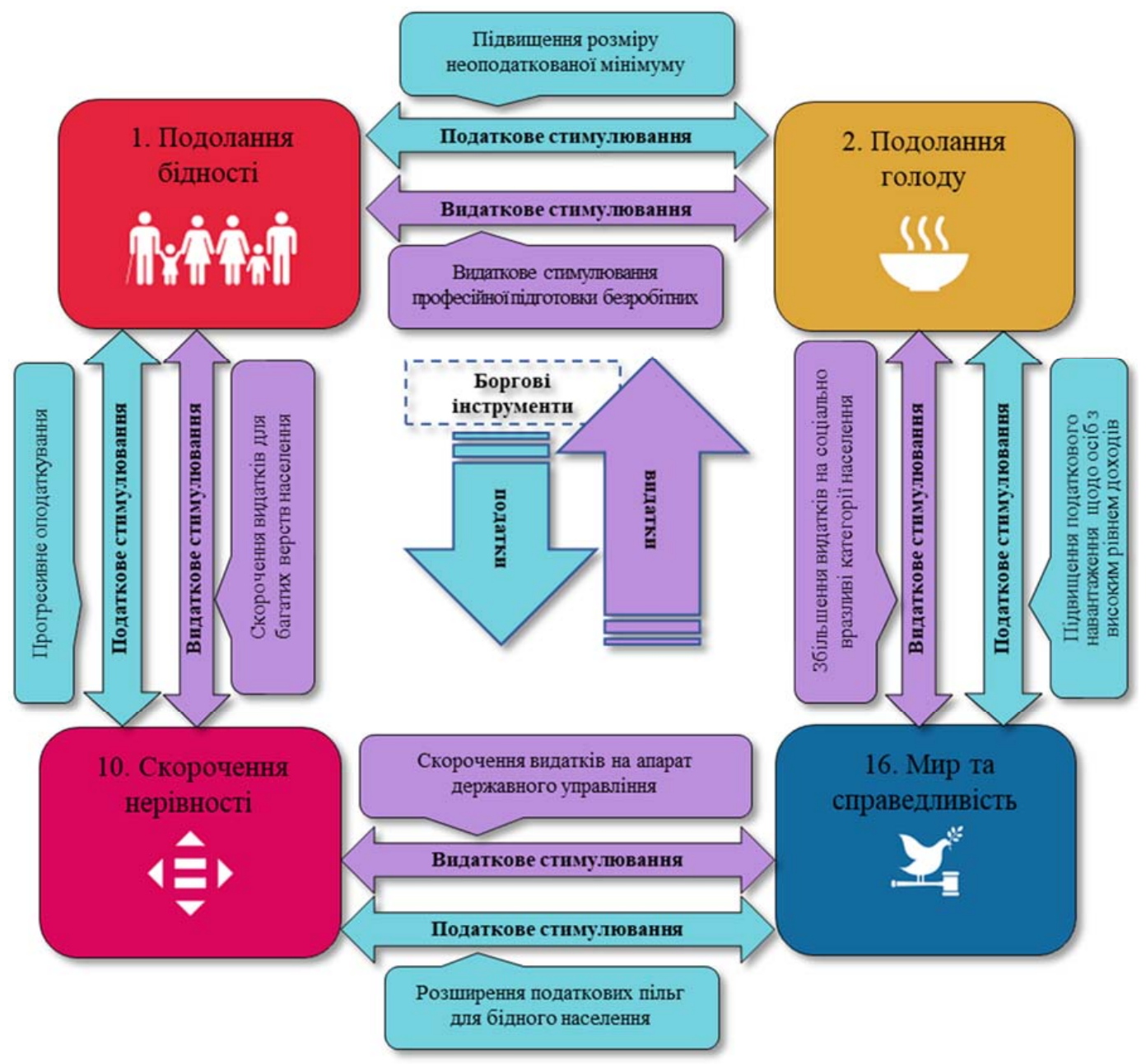

Рис. 1. Використання інструментарію фіскальної політики у досягненні цілей сталого розвитку соціального характеру*

* Побудовано автором.

ни до процесу забезпечення глобальних цілей сталого розвитку.

Світовий досвід використання фіскальних інструментів свідчить, що фіскальна політика держави в кризових ситуаціях має супроводжуватися зниженням податкового тиску та підвищенням рівня державних видатків. Варто наголосити, що в сучасній Україні кількість та ставки податків не є високими. Разом з тим бідність населення, голод та соціальна нерівність $€$ прогресуючими проблемами. 3 рис. 2 можна відстежити негативну тенденцію до зменшення частки доходів найменш забезпеченого населення у загальних доходах населення. При цьому зменшення частки таких доходів відбувається із щорічним підвищенням розмірів мінімальної заробітної плати та прожиткового мінімуму. 


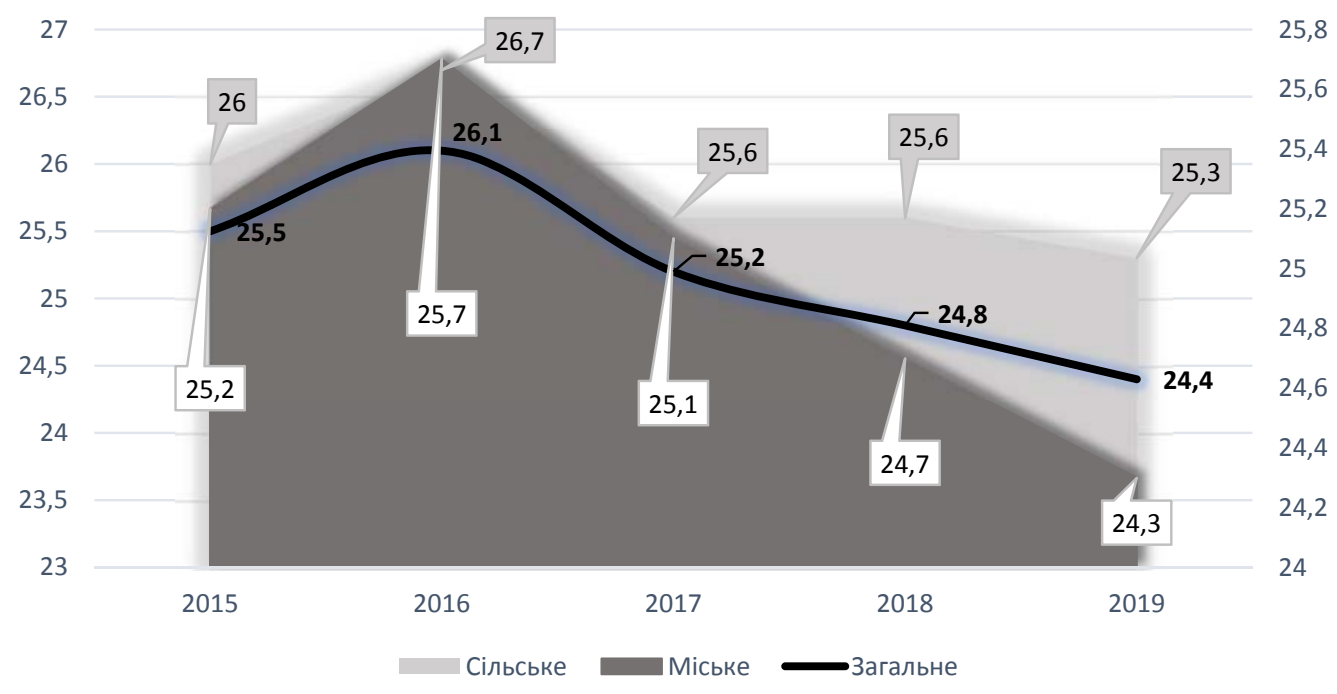

Рис. 2. Динаміка частки загальних доходів $40 \%$ найменш забезпечених у всіх загальних доходах населення, \%*

*Побудовано на основі [7]

Схожість тенденції міського населення із загальним показником пояснюється зменшенням кількості сільського населення через трудову міграцію і, відповідного, зменшенням вагового впливу такого населення на загальний показник.

За таких обставин податковий інструментарій фріскальної політики повинен спрямовуватись на підтримку бідніших верств населення, стимулюючи покращення їх матеріального стану. Характерною ознакою податкового реформування при цьому має бути імплементація прогресивного оподат- кування в систему оподаткування доходів фрізичних осіб. Таке оподаткування існує та не скасовується у більшості економічно розвинутих країн уже десятки років, незважаючи на світові соціально-економічні коливання (табл. 1).

На жаль, Україна з 2004 р. змінила прогресивне оподаткування доходів, впровадивши уніфрікований пропорційний підхід в оподаткуванні. Він створює однакові умови в оподаткуванні для усіх платників, нівелюючи можливість більшої фрінансової участі багатших верств населення у формуван-

Таблиця 1

Граничні ставки особистого прибуткового податку в країнах світу у 2020 р.*

\begin{tabular}{|c||c||}
\hline \hline Країна & Ставки \\
\hline \hline США & від 10 до 37\% \\
\hline \hline Німеччина & від 0 до 45\% \\
\hline \hline Франція & від 0 до 45\% \\
\hline \hline Японія & від 5 до 45\% \\
\hline \hline Україна & $18 \%$ \\
\hline
\end{tabular}

* Складено на основі $[8,9,10,11]$. 
ні фрінансових ресурсів держави. 3 метою зниження податкового тиску на платника та внаслідок такого пропорційного оподаткування пізніше було скасовано утримання 3 працівника єдиного соціального внеску. На нашу думку, існуючий пропорційний підхід в оподаткуванні у довготривалій перспективі стимулює до бідності, голоду, соціальної несправедливості та конфліктів. У цьому контексті прогресивне оподаткування доходів громадян сприяло б зниженню податкового тиску на доходи біднішого населення та його підвищенню щодо населення з високими доходами. Кінцевою стратегічною метою використання прогресивного оподаткування у фіскальній політиці має бути фрормування в Україні середнього класу за прикладом європейських країн, який становив би переважну більшість працездатного населення та був підґрунтям для стабільної і розвинутої України.

У сфрері використання видаткового інструментарію фріскальної політики корисним було б здійснити низку реформувань. В практиці надання соціальної підтримки населенню часто відбувається дублювання функцій соціального захисту. Зокрема, існують програми, що передбачають перевірку доходів, та програми, які надають за належністю до певної категорії.

Система державної соціальної допомоги значною мірою $є$ економічно неефективною, адже часто іїі надають населенню, яке не підпадає під категорію бідного. Це, для прикладу, може стосуватися тих соціальних програм, які передбачають перевірку доходів в умовах, коли в Україні $€$ поширеною практика неофіційного працевлаштування з отриманням незареєстрованих доходів. У таких обставинах ці програми фактично стимулюють неофіційне працевлаштування, сприяючи отриманню додаткових доходів чи компенсації витрат від держави. Варто також згадати категорії громадян
України, які отримують доходи за межами України. Ці особи або їх сім'ї, отримуючи незареєстровані доходи, теж часто користуються програмами державної соціальної підтримки.

Крім того, існує категорія матеріально незабезпечених осіб, які не шукають можливості працевлаштуватись, адже фрактично живуть за рахунок таких адресних допомог. Тому слід обмежувати терміни їх надання з метою стимулювання зайнятості працездатного населення.

На рис. 3 відображені цілі сталого розвитку, що, на нашу думку, пов'язуються із економічним та інноваційним розвитком.

Пріоритетною ціллю у здійсненні фріскальної політики має бути боротьба зі зміною клімату. Існування людини та будь-яких організмів на Землі можливе лише за умови збереження та відновлення природних умов планети. А зміна клімату $є$ наслідком людської життєдіяльності, яка часто має на меті отримання індивідуальних додаткових благ, незважаючи на згубний вплив на природу.

Якісна освіта має надати людству нові технології та рішення щодо розвитку людства, збереження та відновлення природи. Щодо освіти в Україні, то останніми роками держава витрачає на освіту (якщо класифікувати видатки за функціональною класифікацією) чи не найбільше коштів. За даними Міністерства фрінансів України, видатки на освіту у 2019 р. становили 238,8 млрд грн (17,4\% від усіх видатків Зведеного бюджету України) та є більшими за видатки на охорону здоров'я - 128,4 млрд грн, оборону країни 106,6 млрд грн, економічну діяльність - 154,2 млрд грн. За обсягом вони поступаються лише видаткам на соціальний захист та соціальне забезпечення 321,8 млрд грн [12]. Водночас можемо констатувати, що освіта в Україні переживає стадію рецесії і сьогодні багато молодих людей воліють навчатися в коледжах та 


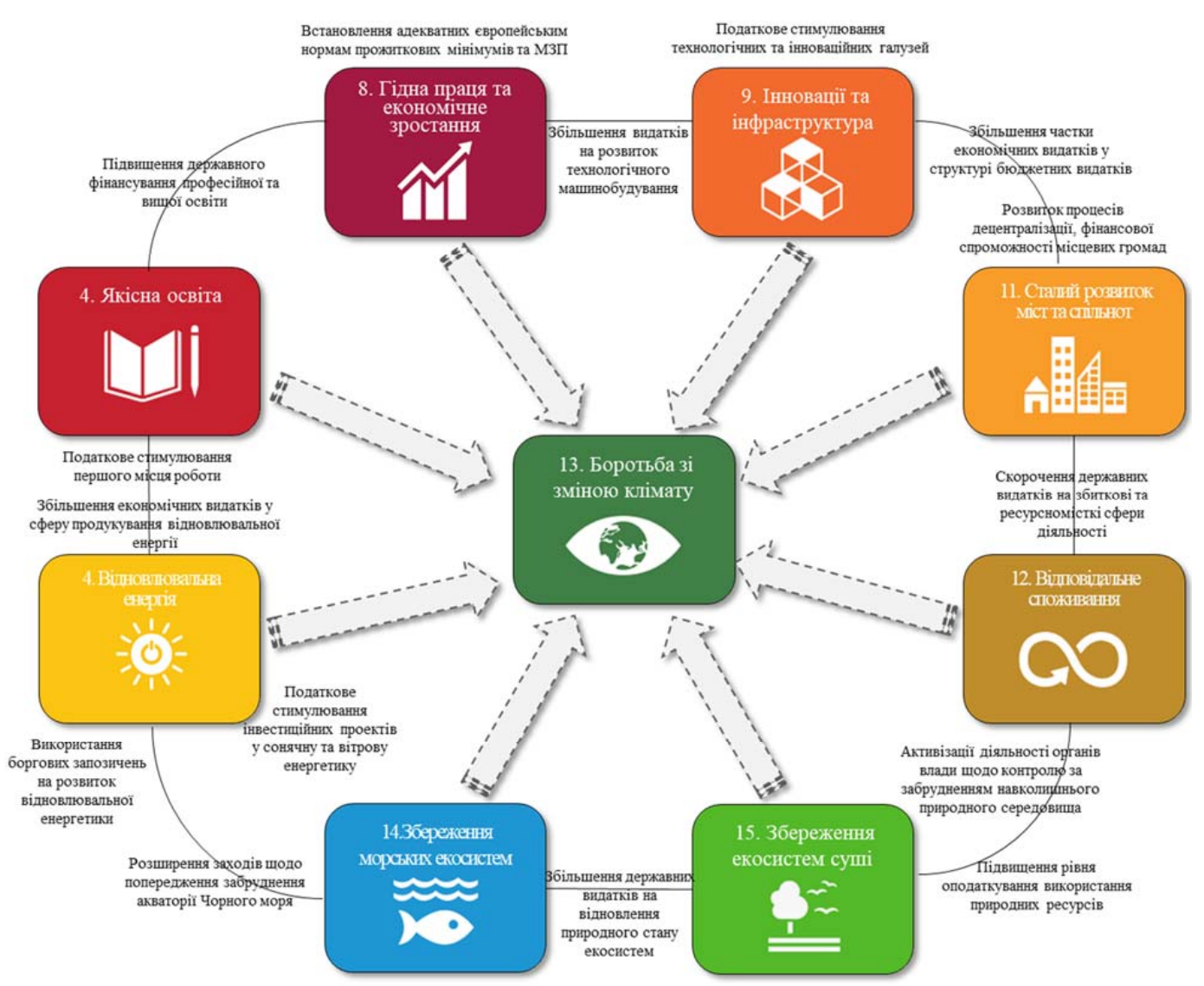

Рис. 3. Використання інструментарію фіскальної політики у забезпеченні цілей сталого розвитку, пов'язаних із інноваціями, розвитком та протидією зміні клімату

університетах інших країнах. 3 іншого боку, попит на кваліфрікованих українських фахівців, особливо технічних спеціальностей, $€$ перманентним у світі. Водночас середня освіта набуває в Україні розвитку, що відповідним чином відображається у її фінансуванні. Не зменшуючи ваги середньої освіти у загальному показнику якості освіти, варто відзначити потребу більшого фрінансування і розвитку вищої освіти в Україні. В іншому випадку ризикуємо втратити вищу освіту як рівень освіти взагалі. Для продукування і розвитку технологій та інновацій, підвищення інтелектуального потенціалу потрібно стимулювати розвиток перспективних спеціальностей вищої освіти. Відсутність такого стимулювання фрактично провокує купівлю послуги вищої освіти за межами України, що стимулює її розвиток в іноземних державах.

У досягненні цілі “Гідна праця та економічне зростання" варто звернути увагу на економічно-обґрунтоване матеріальне стимулювання працівників.

Впровадження інновацій у виробничу інфраструктуру України стимулюватиме перехід від країни-експортера сировини до країни експортера переробної продукції. Важливо впроваджувати ці інновації 3 одночасним збереженням навколишнього 
природного середовища та відновленням природного балансу. Незважаючи на потребу значного фінансування соціального захисту та забезпечення, потрібно поступово підвищувати частку економічних видатків. Держава як суб'єкт економічних відносин потенційно є найбільшим інвестором в економіку. 3 іншого боку, влада країни $є$ регулятором усіх процесів, що відбуваються на іï території. Це має виявлятися в забороні екологічно шкідливих і ресурсо-затратних виробництв, у мінімізації прибуткового оподаткування компаній, які інвестують у інновації, модернізацію та розширення виробництва. Податкове стимулювання має стосуватися лише тих галузей, які застосовують чи інвестують в найсучасніші виробничі потужності. А фріскальні обмеження необхідно накладати лише в тих випадках, коли таке виробництво загрожує безпеці працюючих та довкіллю.

Слід працювати над заміщенням імпорту, тобто надавати податкові преференції тим підприємствам, які здійснюють виробництво якісної альтернативи імпортній продукції.

Сучасні урбаністичні тенденції розвитку людства, які набули поширення і в Україні, свідчать про потребу приділення уваги питанню сталого розвитку міст та спільнот. За 30 років незалежності ми постійно спостерігаємо зменшення частки сільського населення на користь міського. За таких обставин потрібно раціонально підходити до питання розвитку міст та спільнот. Сьогодні уже перменантною стає проблема значних затрат часу на переміщення в межах міст, що впливає на організацію роботи та відпочинку людини. І що більш важливо, значна кількість автомобільного транспорту вкрай негативно впливає на екосистему суші та на зміну клімату загалом. Безумовно, вказану проблему слід вирішувати шляхом розширенням території міських поселень, планування збільшення транспортних сполучень, екологічних насаджень, рекреаційних територій, інших інфраструктурних об'єктів, а також через підвищення екологічних норм до викидів забруднюючих речовин у повітря.

Більшість європейський країн постійно підвищують екологічні вимоги щодо транспортних засобів, що пересуваються автомобільним шляхами країни. У Європі діє екологічний стандарт викиду “Євро6”, власники автомобілів, викиди з яких не відповідають зазначеному стандарту, не мають права пересуватись такими транспортними засобами або ж платять високі податки чи штрафи за порушення стандарту. В Україні ж абсолютно безперешкодно пересуваються автомобілі з викидами забруднюючих речовин, які відповідають стандарту “Євро-2”, “Євро-3”, що були актуальними для Європи у 1995 та 1999 рр. Іншими словами, Україна, яка $\epsilon$, безумовно, європейською країною, відтерміновує впровадження європейських екологічних стандартів на 20 років, порівняно з країнами Євросоюзу. Такі обставини однозначно характеризують ставлення органів влади України до досягнення таких глобальних цілей сталого розвитку, як: боротьба зі зміною клімату; відповідальне споживання, збереження екосистем суші та збереження морських екосистем.

Окрему увагу слід приділяти використанню боргового інструментарію. Наша країна щороку залучає фрінансові ресурси за допомогою боргових запозичень. Це, звичайно, є одним із способів фінансування бюджетних потреб. Але часто запозичення пов'язують із додатковим оподаткуванням майбутніх поколінь, яким потрібно буде погашати ці борги. Та якщо порівняти обсяги зовнішніх запозичень із обсягами виведення фінансового капіталу з країни, то зрозумілим стає фракт, що політика у сфе- 
рі стимулювання інвестицій в національну економіку $є$ не дієвою. За різними підрахунками, обсяги виведених фрінансових ресурсів з України коливаються в межах від 117 млрд дол. до 167 млд дол. [13]. За даними Тах Justice Network, щорічні податкові втрати України через офшшорні операції становлять 28,7 млн дол., а загальні щорічні податкові втрати через операції з іншими країнами, що стосуються уникнення від оподаткування, -650 млн дол. щорічно [14]. Така негативна статистика щодо відтоку капіталу з України мінімізує наші перспективи у досягненні глобальних цілей.

Зважаючи на світовий досвід, виведення капіталу може нести і позитивне явище, коли його використовують як кредитні чи інвестиційні ресурси, що пізніше повертаються в країну походження 3 додатковим прибутком. Але це, на жаль, не стосується нашої країни. Хоч суттєву частку такого вивезеного капіталу його власники невдовзі повертають у формі інвестицій в Україну, але в кінцевому підсумку він осідає в неризикових юрисдикціях - розвинутих країнах світу. Є. О. Бублик вирізняє три форми відтоку капіталу: 1) вивіз (переведення капіталу у зарубіжну юрисдикцію для його легалізації); 2) втеча капіталу (виведення капіталу з ризикових ринків); 3) експорт капіталу (інвестиції в іноземні ринки з більшою дохідністю) [15]. Розділяючи думку автора щодо такої класифікації, зазначимо, що у контексті досягнення цілей сталого розвитку лише третя форма може спричинити позитивний стратегічний ефект для країни походження такого капіталу. В Україні ж спостерігаємо поширення лише перших двох форм відтоку капіталу.

Проблема виведення капіталу пов'язана не із розмірами ставок податків та їх кількістю, а з практикою поширення в країні так званих "нелегальних платежів корупційного характеру”. Тобто, незважаючи на досягнення реального зниження податкового навантаження на платника за основними податками, в нашій країні все ще присутнє явище оплати різних дозволів та фрінансових затрат, спрямованих на отримання конкурентної переваги на ринку.

За даними Національного банку України, у 2019 р. 42,7\% прямих інвестицій в Україну надійшло із Кіпру. У переліку найбільших інвесторів в Україну також $€$ такі країни, як Швейцарія і Люксембург, обсяги інвестицій із яких значно перевищують інвестиції із США, Німеччини [16]. 3 Кіпру надійшло 2,1 млрд дол. прямих інвестицій (інструменти участі у капіталі) у т. ч. 1,5 млрд дол. як реінвестування доходу. Загалом в Україну у 2019 р. надійшло 4,9 млрд дол. з усіх країну світу, в т. ч. 3,3 млрд дол. як реінвестування доходів. За показником залишку прямих інвестицій (інструмент участі в капіталі) в Україну у 2019 р. лідерами є Кіпр - 11,0 млрд дол. та Нідерланди 10,8 млрд дол. I хоча Кіпр, Швейцарія, Люксембург офріційно не входять до переліку затверджених Кабінетом Міністрів України офшорних зон, очевидним $€$ те, що ці країни мають сприятливі умови для залучення фінансового капіталу, який в майбутньому використовується як інвестиційний капітал. Водночас приріст загальної суми державного та гарантованого боргу у 2019 р., порівняно з 2018 р., становив 6 млрд дол. США [17]. Зважаючи на те, що останніми роками такий приріст відбувається за рахунок зростання внутрішнього боргу, то зрозуміло, що суму запозичень можна мінімізувати за рахунок протидії виведенню капіталу та ширшого використання інвестицій.

Беручи до уваги обсяги щорічного використання кредитних фінансових ресурсів і обсяги інвестицій в Україну раніше виведеного капіталу, варто зазначити, що важливим $€$ використання ефективних заходів протидії виведенню капіталу. При цьому 
використання заходів у формі амністії виведеного капіталу, отриманого злочинним способом, є неефективними, оскільки такий капітал вже $є$ легалізованим в іншій країні та щодо нього відсутні юридичні чинники для повернення. Ще однією прихованою формою інвестування в економіку України є кошти, що надходять в Україну за наслідками трудової міграції. Ці індивідуальні інвестиції за рахунок великої кількості трудових мігрантів у підсумку суттєво покращують купівельну спроможність населення України. Такі фрінансові ресурси слід оподатковувати під час споживання товарів і послуг, розглянувши можливість підвищення оподаткування на предмети розкоші чи шкідливі товари для здоров'я або навколишнього середовища.

Дієвим способом протидії відтоку капіталу за кордон $є$ розвиток системи валютного регулювання. У процесі виведення капіталу за межі нашої країни завжди присутній етап валютно-обмінної операції. Забезпечення ефективного валютного регулювання Національним банком України може суттєво зменшити обсяги такого фінансового відтоку капіталу.

Висновки. Результати дослідження підтвердили, що національна фіскальна політика найбільшою мірою може сприяти досягненню глобальних цілей сталого розвитку, однак потенціал її інструментарію в Україні реалізується у не найраціональніший спосіб. Фіскальна політика має регресивний характер, а механізми використання її інструментарію не сприяють досягненню таких цілей сталого розвитку, як боротьба зі зміною клімату, подолання бідності та голоду, скорочення нерівності, якісна освіта, гідна праця та економічне зростання. Відтак перспективи подальших наукових розробок пов'язані із пошуком оптимального поєднання використання інструментів фіскальної політики, коли результатом податково- го, видаткового та боргового регулювання буде досягнення прогресу у досягненні усіх без винятку цілей сталого розвитку.

\section{Список використаних джерел}

1. Atkinson, Giles and Dietz, Simon. Handbook of Sustainable Development, Edward Elgar Publishing. 2007. URL : http://www.communita.com.brl assets/handbookofsustainabledevelopment.pdf.

2. Андрущенко В.Л. Фінансова думка Заходу в XX столітmі (Теоретична концептуалізація і наукова проблематика державних фрінансів). Львів : Каменяр, 2000. 303 с.

3. Козюк В., Шиманська О., Возьний К. Тенденції екологічного оподаткування в Європі. Світ фрінансів. 2019. № 4. С. 8-22.

4. Тулай О., Гумовська I. Сталий людський розвиток: генезис та сучасне бачення в контексті фрінансової науки. Журнал європейської економіки. 2015. T. 14, № 2. С. 149-165.

5. Лібанова Е.М. Людський розвиток в Україні. Оцінка та прогноз рівня життя населення : кол. моногр. / за ред. Е.М. Лібанової. НАН України, Ін-m демографрії та соціальних досліджень імені М.В. Птухи. Київ, 2019. 270 с.

6. Як з'явились цілі сталого розвитку. Програма розвитку ООН в Україні. URL : https://www. ua.undp.org/content/ukraine/uk/home/sustainabledevelopment-goals/background.html.

7. Інформаційне забезпечення моніторингу цілей сталого розвитку. Державна служба статистики України URL : http://www.ukrstat.gov.ual csr prezent/ukr/st rozv/metadata/metadata.htm.

8. IRS provides tax inflation adjustments for tax year 2020. URL : https://www.irs.gov/newsroom/ irs-provides-tax-inflation-adjustments-for-taxyear-2020.

9. Germany. Individual - Taxes on personal income. Worldwide Tax Summaries Online. PwC. URL : https://taxsummaries.pwc.com/germany/individual/taxes-on-personal-income.

10. French tax summary 2021. France Accountants. URL : https://www.europeaccountants. com/france/tax. 


\section{ПОДАТКИ І ФІСКАЛЬНА ПОЛІТИКА}

11. International Tax. Japan Highlights 2020. Deloitte. URL : https://www2.deloitte.com/content/ dam/Deloitte/global/Documents/Tax/dttl-tax-japanhighlights-2020.pdf?nc=1.

12. Бюджетна політика. Попередні бюджеmu. Міністерство фрінансів України. URL : https:// www.mof.gov.ua/uk/previous-years-budgets.

13. Кораблін С. Офшорне виснаження. Дзеркало тижня. 2016. 13 травня. URL : https://zn.ual ukr/macrolevel/ofshorne-visnazhennya- .html.

14. The State of Tax Justice URL: https://www. taxjustice.net/reports/the-state-of-tax-justice-2020/.

15. Бублик $€$. О. Особливості втечі капіталу в транзитивних економіках. Ефрективна економіка. 2020. №2. URL : http://www.economy. nayka.com.ua/pdf/2_2020/54.pdf.

16. Статистика зовнішнього сектору. Національний банк України. URL : https://bank.gov.ual ua/statistic/sector-external/data-sector-external\#5.

17. Державний борг та гарантований державний боре. Міністерство фрінансів України. URL : https://mof.gov.ua/uk/derzhavnij-borg-tagarantovanij-derzhavju-borg.

\section{References}

1. Atkinson, Giles and Dietz, Simon. (2007). Handbook of Sustainable Development, Edward Elgar Publishing. Available at: http://www.communita.com.br/assets/handbookofsustainabledevelopment.pdf.

2. Andrushchenko, V. L. (2000). Finansova dumka Zakhodu v XX stolitti (Teoretychna kontseptualizatsiia $i$ naukova problematyka derzhavnykh finansiv) [Financial thought of the West in the $X X$ century]. Lviv: Kameniar [In Ukrainian].

3. Koziuk, V., Shymanska, O., Voznyi, K. (2019). Tendentsii ekolohichnoho opodatkuvannia $v$ Yevropi [Trends of environmental taxation in Europe]. Svit finansiv - World of Finance, 4, 8-22 [In Ukrainian].

4. Tulai, O., Humovska, I. (2015). Stalyi liudskyi rozvytok: henezys ta suchasne bachennia $v$ konteksti finansovoi nauky [Sustainable human development: genesis and modern vision in the context of financial science]. Zhurnal yevropeiskoi ekonomiky - The Journal of European Economy, 2, 149-165 (Vol. 14) [In Ukrainian].

5. Libanova, E. M. (Ed.). (2019). Liudskyi rozvytok v Ukraini. Otsinka ta prohnoz rivnia zhyttia naselennia [Human development in Ukraine. Assessment and forecast of living standards]. NAN Ukrainy, In-t demohrafii ta sotsialnykh doslidzhen imeni M.V. Ptukhy. Kyiv [In Ukrainian].

6. Yak ziavylys tsili staloho rozvytku. Prohrama rozvytku OON v Ukraini [How sustainable development goals came about. UN Development Program in Ukraine]. Available at: https://www.ua.undp.org/ content/ukraine/uk/home/sustainable-development-goals/background.html.

7. Informatsiine zabezpechennia monitorynhu tsilei staloho rozvytku. Derzhavna sluzhba statystyky Ukrainy [Information support for monitoring the goals of sustainable development]. Available at: http://www.ukrstat.gov.ua/csr prezent/ukr/st rozv/ metadata/metadata.htm.

8. IRS provides tax inflation adjustments for tax year 2020. Available at: https://www.irs.gov/ newsroom/irs-provides-tax-inflation-adjustmentsfor-tax-year-2020.

9. Germany. Individual - Taxes on personal income. Worldwide Tax Summaries Online. PwC. Available at: https://taxsummaries.pwc.com/germany/individual/taxes-on-personal-income.

10. French tax summary 2021. France Accountants. Available at: https://www.europeaccountants.com/france/tax.

11. International Tax. Japan Highlights 2020. Deloitte. Available at: https://www2.deloitte.com/ content/dam/Deloitte/global/Documents/Tax/dttltax-japanhighlights-2020.pdf?nc=1.

12. Biudzhetna polityka. Poperedni biudzhety [Budget policy. Previous budgets]. Ministerstvo finansiv Ukrainy. Available at: https://www.mof.gov. ua/uk/previous-years-budgets.

13. Korablin, S. (2016). Ofshorne vysnazhennia [Offshore depletion]. Dzerkalo tyzhnia - Mirror of the Week. Available at: https://zn.ua/ukr/macrolevel/ofshorne-visnazhennya-. html. 


\section{ПОДАТКИ І ФІСКАЛЬНА ПОЛІТИКА}

14. The State of Tax Justice. Available at: https://www.taxjustice.net/reports/the-state-of-taxjustice-2020/.

15. Bublyk, Y. O. (2020). Osoblyvosti vtechi kapitalu v tranzytyvnykh ekonomikakh [Features of capital escape in transition economies]. Efektyvna ekonomika - Efficient Economy, 2. Available at: http://www. economy.nayka.com.ua/pdf/2 2020/54.pdf.

16. Statystyka zovnishnoho sektoru [External sector statistics]. Natsionalnyi bank Ukrainy - National Bank of Ukraine. Available at: https:// bank.gov.ua/ua/statistic/sector-external/datasector-external\#5.
17. Derzhavnyi borh ta harantovanyi derzhavnyi borh [Public debt and guaranteed public debt]. Ministerstvo finansiv Ukrainy - Ministry of Finance of Ukraine. Available at: https://mof.gov.ua/ uk/derzhavnij-borg-ta-garantovanij-derzhavju-borg.

Стаття надійшла до редакції 30.10.2020. 